\title{
Analysis of Determining Factors for Successful Implementation of Village Financial Management
}

\author{
Levina Kristiani Yusar \\ Faculty of Economics and Business \\ Universitas Padjadjaran \\ Sri Mulyani \\ Faculty of Economics and Business \\ Universitas Padjadjaran
}

\begin{abstract}
This study aims to determine the critical success factors in the implementation of village financial management. The research is a case study research that is conducted in three villages with different village status, namely developed villages, developing villages and underdeveloped villages in Talun Sub-District, Cirebon Regency. Data collection was carried out through interviews with village heads, secretaries, treasurers and the Village Consultative Body (BPD). The results showed that the implementation of village financial management (planning, implementation, administration, reporting and accountability) in the three villages studied, had been carried out under Regulation of the Minister of Home Affairs Number Number 113/2014 concerning guidance for village financial management, However, village financial administration, had not carried out following the rules. The study suggests that there three main factors for the successful implementation of village financial management, namely the competence of village government officials, commitment and support from leaders, and the role of the village consultative body. Secondary factors for the successful implementation of village financial management are the participation and support from the community and understanding in running the SISKEUDES application.
\end{abstract}

Keywords: critical success factors; village financial management; accountability; SISKEUDES application

\section{Introduction}

The village fund policy was implemented in Indonesia in 2025, and the total budget allocation for the village fund is increasing every year. The village government must consider the transparency and accountability of village fund management. This study aims to determine the critical success factors of village financial management implementation in three villages in Talun Sub-District, Cirebon Regency.

Transparency and accountability are public finance principles which are not only the obligations and responsibilities of the central government but must also be considered by local and village governments. The law number $6 / 2014$ concerning villages states that a village is the legal community unit that has territorial boundaries authorized to regulate and manage government affairs, the interests of the local community based on community initiatives, origin rights, and / traditional rights that are recognized and respected in the government system of the unitary Republic of Indonesia.

In order to support the realization of good governance in the management of village financial, the government has issued regulation of the minister of home affairs number 113/2014 
concerning guidelines for village financial management. It covers all activities including planning, implementing, administering, reporting, accountability to village financial supervision, in it, regulates the principles that must be practised in managing village finances to achieve good governance, including transparent, accountable, participatory, orderly and budgetary discipline (Article 2). Village finance includes elements, namely village income, village expenditure, financing, and village financial management. The village fund is one part of village income.

In 2015, the village fund policy was implemented in Indonesia with a total allocation of Rp. 20 trillion. The total allocation of village funds increased dramatically in the following year to Rp 46.9 trillion. The allocation of village funds then increased by almost $30 \%$ to Rp. 60 trillion in 2017. Within three years, the budget allocation for village funds has tripled. In managing village funds, the village is obliged to conduct accounting to support the process of accountability and transparency of village fund to the public. The following data is a breakdown of village funds per Regency / City issued by the Ministry of Finance for the fiscal year 2018, for the Province of West Java as follows:

Table 1. Fund Village Allocation in West Java Province

\begin{tabular}{|c|c|c|c|c|c|c|}
\hline Regency / City & $\begin{array}{c}\text { Total } \\
\text { Villages }\end{array}$ & $\begin{array}{l}\text { Base Allocation for } \\
\text { each village }\end{array}$ & $\begin{array}{c}\text { Base } \\
\text { Allocation }\end{array}$ & $\begin{array}{l}\text { Affirmation } \\
\text { Allocation }\end{array}$ & $\begin{array}{c}\text { Formulation } \\
\text { Allocation }\end{array}$ & Total \\
\hline Total West Java Province & 5.312 & 11.710 .555 & $\begin{array}{c}3.274 .024 .64 \\
0\end{array}$ & 188.839 .164 & 1.360 .231 .614 & $\begin{array}{c}4.823 .095 .41 \\
8\end{array}$ \\
\hline Bogor Regency & 416 & 616.345 & 256.399 .520 & 18.089 .733 & 128.495 .688 & 402.984 .941 \\
\hline Sukabumi Regency & 381 & 616.345 & 234.827 .445 & 10.883 .254 & 62.016 .828 & 307.727 .527 \\
\hline Cianjur Regency & 34 & 616.345 & 218.186 .130 & 22.060 .650 & 109.082 .672 & 349.329 .452 \\
\hline Bekasi Regency & 180 & 616.345 & 110.942 .100 & 7.647 .692 & 78.681 .875 & 197.271 .667 \\
\hline Karawang Regency & 297 & 616.345 & 183.054 .465 & 16.766 .094 & 80.330 .773 & 280.151 .332 \\
\hline Purwakarta Regency & 13 & 616.345 & 112.791 .135 & 3.088 .491 & 25.618 .229 & 141.497 .855 \\
\hline Subang Regency & 245 & 616.345 & 151.004 .525 & 2.206 .065 & 32.939 .492 & 186.150 .082 \\
\hline Bandung Regency & 270 & 616.345 & 166.413 .150 & 9.412 .544 & 85.808 .016 & 261.633 .710 \\
\hline Sumedang Regency & 270 & 616.345 & 166.413 .150 & 1.176 .568 & 25.103 .625 & 192.693 .343 \\
\hline Garut Regency & 421 & 616.345 & 259.481 .245 & 22.943 .076 & 118.772 .594 & 401.196 .915 \\
\hline Tasikmalaya Regency & 351 & 616.345 & 216.337 .095 & 15.883 .668 & 93.330 .539 & 325.551 .302 \\
\hline Ciamis Regency & 258 & 616.345 & 159.017 .010 & 6.471 .124 & 54.802 .418 & 220.290 .552 \\
\hline Cirebon Regency & 412 & 616.345 & 253.934 .140 & 11.765 .680 & 105.122 .102 & 370.821 .922 \\
\hline Kuningan Regency & 361 & 616.345 & 222.500 .545 & 2.794 .349 & 36.650 .148 & 261.945 .042 \\
\hline Indramayu Regency & 309 & 616.345 & 190.450 .605 & 13.383 .461 & 109.600 .688 & 313.434 .754 \\
\hline Majalengka Regency & 330 & 616.345 & 203.393 .850 & 12.501 .035 & 99.796 .656 & 315.691 .541 \\
\hline Bandung Barat Regency & 165 & 616.345 & 101.696 .925 & 8.677 .189 & 89.189 .633 & 199.563 .747 \\
\hline Pangandaran Regency & 93 & 616.345 & 57.320 .085 & 2.647 .278 & 17.459 .846 & 77.427 .209 \\
\hline Banjar City & 16 & 616.345 & 9.861 .520 & 441.213 & 7.429 .792 & 17.732 .525 \\
\hline
\end{tabular}

Cirebon Regency as the third-highest recipient of village funds in West Java Province in 2018 amounted to $\mathrm{Rp} 370,821,922,000$. Unfortunately, the massive allocation of village funds also raises new problems, namely the occurrence of cases of corruption in villages in Cirebon Regency. It is because the village budget received is quite large and continues to increase every year but is not accompanied by 
the implementation of the principles of public financial management properly.

Indonesian Corruption Watch (ICW) notes that there have been 154 cases of corruption in village funds. Various forms of corruption, among others, are embezzlement of money, the misuse of the budget and authority, the imposition of extortion, mark up, giving false reports, and cutting the budget to bribery. The majority of Village Heads become the main elements who commit criminal acts of corruption in village funds. During 2015 until 2017, 112 village heads committed corruption, and each year continues to significant increases. ICW researcher, Almas Sjafrina, said that four factors caused corruption, namely: the community was less involved in the planning and supervision process, the competence of village heads and village officials was limited, the performance of village institutions was not optimal, and the fact that there was a high political cost caused by competitive village head elections process (Pikiran Rakyat, August 11, 2017).

According to S.Mulyani, Puspitasari and Yunita (2018), the factors that support the successful implementation of accrual-based government accounting are the commitment of leaders, human resource capabilities, local regulations that support implementation, coordination and communication with internal and external auditors, and accounting information technology. In this study, the factors that will be explored to be analyzed are human resource competencies, organizational and leadership commitment, and the role of the Village Consultative Body (BPD), as determinants of the successful implementation of village financial management. The study was conducted in three villages in Talun SubDistrict, Cirebon Regency.

\section{Literature review}

\section{Village Financial Management Concepts}

Based on the minister of home affairs regulation No. 113/2014 concerning the guidance of village financial management states that the village head is the authority of village financial management. In implementing village financial management, the village head is assisted by PTPKD (Village Financial Management Technical Implementer), consists of Village Secretary, Division Head and Treasurer. The following is a chart of village financial managers:

Figure 1. Structure of Village Governmental Administration

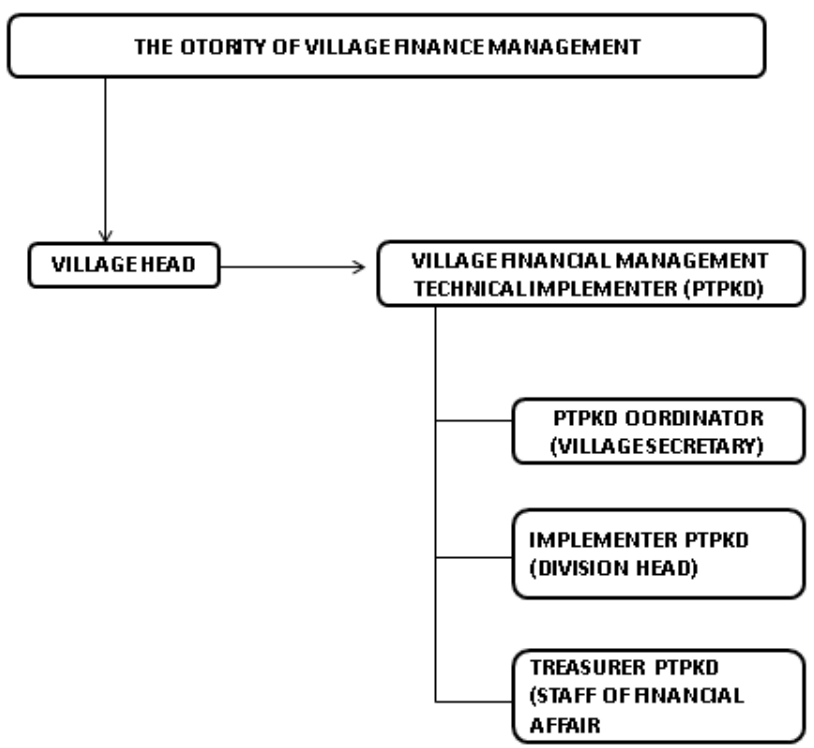




\section{Village financial management process}

Village Finance is the main resource for village governments to carry out village governance and development, also a picture of the development of Village, Village and Village Communities. In the Minister of Domestic Affairs Regulation No. 113 of 2014 concerning Village Financial Management, Chapter VII Article 72 concerning village finances and assets, it is explained that the sources of village income are: 1) Village Original Income is the results of operations, asset results, self-help and participation, mutual cooperation, and other Village original income; 2) National Revenue and Expenditure Budget (APBN) Allocation; 3) Part of the results of regional taxes and levies Regency / City; 4) Village fund allocation is part of the balance funds received by the Regency / City; 5) Financial assistance from the Provincial, Regency / City APBD; 6) Non-binding grants and donations from third parties; 7) Legal village income

The village financial management cycle based on the Minister of Home Affairs Regulation Number 113 of 2014 covers all activities starting from:

\section{1) Planning}

There is a role of the village secretary in drafting the Village Regulation on the Village Revenue and Expenditure Budget (APBDes) based on the Village Work and Development Plan (RKPDes) which will be delivered directly by the village head. Then there is the role of the BPD to discuss and agree on the Village Regulation Draft.

2) Implementation

Starting with the creation of a village cash account in the context of exercising village authority. Submission of disbursement of village funds must be accompanied by documents, such as RAB (Expenditure Budget) which is verified by the village secretary and approved by the village head. The role of the village treasurer in the process of implementing village finance is to participate in collecting income tax $(\mathrm{PPh})$ and other taxes.

\section{3) Administration}

The process of administration must be carried out by the village treasurer to account for all village finances by recording each receipt and expenditure of village funds and closing the books at the end of each month in an orderly manner. At the end of each month, the village treasurer produces an accountability report that will be submitted to the village head.

4) Reporting

The village head submits a report on the realization of the APBDes to the Regent / Mayor in the form of a semester report.

5) Accountability

The village head submits the accountability report on the realization of the APBDes to the Regent / Mayor at the end of the fiscal year.

\section{Research methods}

This research is a case study in three villages, in Talun sub-district, Cirebon Regency, namely Kepongpongan Village, Ciperna Village and Sampiran Village. Each of the three villages represented the village category, namely developed, developed, and disadvantaged villages. The selection of representatives from each of these village categories is expected to provide a complete picture of the problem under study. The data used in this study are primary data obtained through interviews with informants from each village. The tools used in the data collection process are interview guidelines that are arranged according to the objectives and theories that are used as references, and recording devices with approval from the speakers.

The informants in this study were the village head; The Village Financial Management Technical Implementation (PTPKD) consists of the village secretary and village treasurer; and the Village Consultative Body (BPD). Data obtained from informants regarding the determinants of successful implementation of village financial management will be grouped according to village status/categories. 
Data validity was tested using triangulation techniques. There are four types of triangulation as a technique in achieving validity, namely: Data Triangulation, Observer Triangulation, Theory Triangulation and Method Triangulation. In this research, triangulation techniques used are data triangulation, theories and methods. For the purposes of data reliability, a database is compiled as evidence of collected research data which is stored in the form of recorded interviews to facilitate researchers in processing data and reducing the bias of information.

Data analysis is carried out to systematically find data obtained from interviews, field notes and documentation by reducing data into categories, detailing into units, synthesizing and then concluding so that it is easy to understand. (Miles and Huberman, 1994 in Sekaran and Bougie, 2013 and Sugiyono, 2017). The stages of data analysis are as follows:
1) Data Reduction

At this stage, summarizes and selects data based on key points in the field to facilitate researchers in making data conclusions.

2) Data Presentation

At this stage, data are presented in a short form to facilitate and understand what is happening.

3) Conclusion / Verification

In this stage, the researcher will make conclusions supported by valid and consistent evidence that has been obtained.

\section{Results and Discussion}

Implementation of village financial management

Implementation of 5 processes in village financial management following minister of home affairs regulation No. 113/2014 concerning village financial management, in Kepompongan village, is as follows:

Table 2. Implementation of village financial management in Kepongpongan Village

\begin{tabular}{|c|c|c|c|c|}
\hline Planning Process & $\begin{array}{c}\text { Implementation } \\
\text { Process }\end{array}$ & Administration Process & Reporting Process & Accountability Process \\
\hline $\begin{array}{l}\text { Involving the } \\
\text { community by } \\
\text { holding } \\
\text { deliberations at the } \\
\text { RT / RW level, } \\
\text { hamlet level and } \\
\text { deliberations at the } \\
\text { village level. } \\
\text { The purpose of } \\
\text { deliberations is to } \\
\text { determine the } \\
\text { priority in the } \\
\text { allocation of village } \\
\text { funds for village } \\
\text { development. }\end{array}$ & $\begin{array}{l}\text { Use of village } \\
\text { account for all } \\
\text { village financial } \\
\text { activities, including } \\
\text { receipt, expenditure } \\
\text { and disbursement of } \\
\text { village funds } \\
\text { The treasurer } \\
\text { carries out his } \\
\text { duties, overseen by } \\
\text { the village head. } \\
\text { Village funds } \\
\text { disbursed from the } \\
\text { account are given to } \\
\text { the TPK (Activity } \\
\text { Implementation } \\
\text { Team) for the } \\
\text { purpose of carrying } \\
\text { out the activities. }\end{array}$ & $\begin{array}{l}\text { The village treasurer } \\
\text { administrates village } \\
\text { funds including cash } \\
\text { receipts and } \\
\text { disbursements, tax } \\
\text { collection (PPh and } \\
\text { PPN). Administration of } \\
\text { village funds uses a } \\
\text { book of general cash, the } \\
\text { book of tax, which are } \\
\text { done manually. }\end{array}$ & $\begin{array}{l}\text { The village } \\
\text { financial } \\
\text { management } \\
\text { process has been } \\
\text { reported in the } \\
\text { form of semester } \\
\text { reports and LKPJ } \\
\text { to BPD in a timely } \\
\text { manner }\end{array}$ & $\begin{array}{l}\text { The accountability report } \\
\text { (LPJ) is submitted to the } \\
\text { regency's internal auditor / } \\
\text { sub-district annually. } \\
\text { Reports of village funds are } \\
\text { disclosed to the community } \\
\text { in village meetings } \\
\text { Transparency of the village } \\
\text { fund is also disclosed to the } \\
\text { community by the } \\
\text { installation of billboards } \\
\text { which informed village's } \\
\text { revenue, in the village } \\
\text { head's office }\end{array}$ \\
\hline
\end{tabular}

From information on the process of implementing village financial management in Kepompongan Village, it can be seen that village officials have understood the duties and responsibilities of each in the village financial management process.

Implementation of 5 processes in village financial management following minister of 
home affairs regulation No. 113/2014 concerning village financial management, in

Ciperna Village, is as follows:

Table 3. Implementation of village financial management in Ciperna Village

\begin{tabular}{|c|c|c|c|c|}
\hline Planning Process & $\begin{array}{c}\text { Implementation } \\
\text { Process }\end{array}$ & $\begin{array}{c}\text { Administration } \\
\text { Process }\end{array}$ & Reporting Process & Accountability Process \\
\hline $\begin{array}{l}\text { The village } \\
\text { government engages } \\
\text { the community } \\
\text { through } \\
\text { deliberations at the } \\
\text { RT / RW level, } \\
\text { hamlet level, and } \\
\text { village level. } \\
\text { The purpose of the } \\
\text { deliberations is to } \\
\text { determine the } \\
\text { priority for using } \\
\text { village funds for } \\
\text { village development. }\end{array}$ & $\begin{array}{l}\text { The treasurer and } \\
\text { the village head } \\
\text { disbursed the budget } \\
\text { and withdrew } \\
\text { money from the } \\
\text { bank. The money } \\
\text { was then given to } \\
\text { the TPK (Activity } \\
\text { Implementation } \\
\text { Team) to carry out } \\
\text { the activities. }\end{array}$ & $\begin{array}{l}\text { The treasurer only } \\
\text { collects taxes assisted } \\
\text { by RT / RW }\end{array}$ & $\begin{array}{l}\text { LPJ is made based on the } \\
\text { evidence of transactions } \\
\text { (memorandum) } \\
\text { collected. }\end{array}$ & $\begin{array}{l}\text { LPJ is submitted to the } \\
\text { regency's internal auditor / } \\
\text { Sub-District. }\end{array}$ \\
\hline
\end{tabular}

Based on the information above, it can be identified that the implementation of village fund management in Ciperna Village has not been carried out perfectly in accordance with the minister of home affairs regulation No. $113 / 2014$ concerning village financial management. According to the interviewed informant, this was due to the lack of understanding by the village officials regarding the regulation.

Implementation of 5 processes in village financial management following minister of home affairs regulation No. 113/2014 concerning village financial management, in Sampiran village, is as follows:

Table 4. Implementation of village financial management in Sampiran village

\begin{tabular}{|c|c|c|c|c|}
\hline Planning Process & $\begin{array}{c}\text { Implementation } \\
\text { Process }\end{array}$ & Administration Process & $\begin{array}{c}\text { Reporting } \\
\text { Process }\end{array}$ & Accountability Process \\
\hline $\begin{array}{l}\text { Deliberations are } \\
\text { held at the hamlet } \\
\text { level (Musdus) and } \\
\text { then followed by a } \\
\text { Village Deliberation } \\
\text { (Musdes) with the } \\
\text { aim of } \\
\text { accommodating } \\
\text { aspirations and } \\
\text { setting priorities for } \\
\text { village development. }\end{array}$ & $\begin{array}{l}\text { The treasurer did not } \\
\text { explain the process } \\
\text { of disbursement of its } \\
\text { distribution in detail. } \\
\text { The village secretary } \\
\text { explained that at this } \\
\text { stage a TPK / } \\
\text { TPPKD was formed. }\end{array}$ & $\begin{array}{l}\text { The treasurer did not } \\
\text { understand this process. } \\
\text { The village secretary } \\
\text { helps the treasurer to } \\
\text { collect memorandum of } \\
\text { expenditure based on the } \\
\text { RAB. }\end{array}$ & $\begin{array}{l}\text { Make SPJ and will } \\
\text { be inspected } \\
\text { annually by the } \\
\text { District / } \\
\text { Regency's internal } \\
\text { auditor }\end{array}$ & $\begin{array}{l}\text { LPJ is submitted to sub- } \\
\text { district }\end{array}$ \\
\hline
\end{tabular}

Based on the information implementation of the village fund management process in Desa Sampiran above it can be seen that the management of village funds is not fully following the minister of domestic affairs regulation No. 113/2014 concerning village 
financial management. The results of the interview obtained information that the treasurer of the village of Sampiran who did not understand the administration stage.

\section{Determinants of Successful Implementation of Village Financial Management}

Based on interviews and analysis of information obtained by researchers in the field, there are three factors that determine the successful implementation of village financial management, namely: the competence of village government officials, organizational commitment and leadership commitment, and the role of the Village Consultative Body (BPD) as a supervisory body. The following is an explanation of these three factors:

\section{Human Resource Competencies}

Human resources are the main controller in an organization or agency and become a factor that can determine organizational achievement. Within the village scope, human resources are the village head and the village officials as the holder of the village financial management authority. Hutapea and Thoha (2008: 28), define three main components of competence, namely: knowledge, skills and attitudes. Following is a description of human resource competencies in the three villages studied.

Kepongpongan Village, the competence of human resources owned by the Kepongpongan village government, has had a significant impact on the implementation of village fund management. Education of village government apparatus in Kepongpongan is generally high school/equivalent. In contrast, the education of the village head, village treasurer and head of planning affairs are undergraduates (S1). The village head requires all village government officials to take part in training conducted by the Regency / Sub-District. The village government also held training for the community, which was held in the village. Village government officials shared knowledge among other government officials, obeyed the rules and began to apply PDLT (Achievement, Dedication, Loyalty and Impeccable) to all government officials in his village. Kepongpongan village government officials have been responsible and exercise authority in the village financial management process.

Ciperna Village, the education of village government officials in Ciperna village, is generally high school/equivalent. Only village treasurers have a bachelor's degree. Ciperna Village Government also conducts training in the framework of empowering human resources, which is conducted between two to three times a year. Village government officials also share knowledge between officials, and also exercise their authority and responsibility in managing village funds, although there is still a lack of understanding of their obligations and duties in detail. The village government applies work discipline in the form of a fingerprint.

Sampiran Village, the education of the village government apparatus in general, is high school/equivalent and there are still some village officials who take the package $\mathrm{C}$ test. Also, initiatives have begun to hold training in local villages. Among the village officials, knowledge sharing was also carried out. The village government plans to develop an order and impose sanctions if it is not obeyed.

\section{Organization Commitment}

Organizational commitment is a determination to stick to the goals, values and conditions that have been determined in an organization. The key to the success of a change in the scope of the organization is implemented with the support and strong action from the leadership to be manifested in implementing a policy in the organization (Robbins, 2002). Following are the results of research on organizational commitment in the implementation of village fund management in the three villages studied.

Kepongpongan Village, The main objective of the village government, is to provide services to the community. Kepongpongan Village has provided services to 
the community following the provisions and values of the village community in carrying out their obligations, with high commitment. The village fund is communicated directly to the community through village meetings. It usually is conducted at the beginning of the year before budget implementation and at the end of the year to communicate the results of the realization of the APBDes and LPJ. Besides, the installation of billboards in the village head's office for one fiscal year as a form of transparency of the Kepongpongan village government to the community. Village facilitation from the subdistrict to direct the performance of village officials and the existence of rules that serve as guidelines in carrying out their duties are forms of leadership support in influencing the behaviour and attitudes of Kepongpongan village government officials. Likewise, the existence of inspections carried out by the subdistrict and district government internal auditor is a manifestation of the commitment of the village government and regional governments in the implementation of village financial management.

Ciperna Village, the Ciperna village government, embodies its organizational commitment in providing services to the community, namely by trying to carry out village financial management well. This form of commitment includes the delivery of information on village financial management directly to the community through deliberations, installation of billboards. At the end of the year, the final results of village development are communicated in the form of realization and LPJ reports on the implementation of the APBDes in village meetings. Strong support from leadership is one of the keys to success that affects the organizational commitment of Ciperna village government officials. The form of support is the allocation of village funds to meet the needs of the community both infrastructure and empowerment, as well as training to village officials, village assistance, as well as annual inspections by the sub-district and inspectorate.

Sampiran Village, the organizational commitment showed by the village government, especially in terms of village financial management, among others by communicating with the community in village meetings, also installing billboards at the village office informing village funds. At the end of the year the final results of the village development were communicated in the form of a realization report and LPJ from the implementation of the APBDes, but they were not informed in the village deliberations, only to the district government internal auditor. Forms of support from local and central government include providing training and coaching for village government, as well as examinations conducted by the sub-district and regency's internal auditor.

\section{The Role of the Village Consultative Body}

The Village Consultative Body (BPD) as explained in Law Number 6 of 2014 concerning Villages, article 55 generally has a function including discussing and agreeing on a Village Regulation Draft with the village head, accommodating and distributing the aspirations of the village community, monitoring the performance of the village head. Following are the results of research on the role of BPD in village financial management in the three villages studied:

Kepongpongan Village, the Village Consultative Body (BPD) of Kepongpongan village is always involved in providing opinions and approvals for each village's affairs. The Village Consultative Body in Kepongpongan village carries out its functions following Law No. 6 of 2014 concerning the village, article 55 namely overseeing the performance of village officials, especially village heads, capturing community aspirations and participating in determining village regulations through deliberations. Besides, the authority and responsibility of the BPD are to carry out the legislative function for the administration of the village of Kepongpongan.

Ciperna Village, The role of the Village Consultative Body in the village of Ciperna is as a partner in fostering the village, overseeing the village administration in managing village finances or providing services to the community. The authority and responsibility have been 
implemented by the Ciperna BPD, namely supervising the implementation of the program and the realization of the APBDes and in the process of village financial accountability.

Sampiran Village, The Village Consultative Body in the village of Sampiran, had experienced an internal problem that some members resigned because they could not flexibly deal with problems in the village government or the community. At present, BPD as a mobilizer in conducting meetings in the village and is considered quite helpful. Besides, BPD participated in making village regulations and approving the APBDes that were made. Authority and responsibility carried out by BPD close to achieving success in village financial management have not been done to the fullest because several BPD members are vacuum.

\section{Conclusions}

Based on the results of the analysis and discussion that have been presented previously, the researcher obtained the following conclusions The three villages, namely villages that advance, developing, and underdeveloped, have implemented village financial management based on the minister of home affairs regulation No. 113/2014 concerning the management of village finance. There are differences in understanding of the implementation of the management of village finances. This resulted in differences in the success of the implementation of village financial management in the three villages.

Information from informants interviewed in the three villages explains that the factors that determine the successful implementation of village financial management are organizational commitment and support from the leadership, human resource competencies and the role of the Village Consultative Body in carrying out supervisory functions following Law No. 62014 concerning Village. Other supporting factors are the participation and support from the community and understanding in running the SISKEUDES application.
This research has a limitation; namely, some informants were only willing to answer some of the questions raised and could not explain in detail because they did not understand the main tasks and functions. In the future, the researcher should get informants from other sources such as the staff of village empowerment affair of the district office, or researchers try to observe the business process of village financial management in the village. Recommendation, researchers then need to use other data collection techniques, such as observation, to obtain more comprehensive data. Village government needs to strengthen at least those three factors so that the implementation of village financial management will be proper.

\section{Bibliography}

Budimanta, Arif. dkk. (2008). Corporate Social Responsibility : Alternatif bagi Pembangunan Indonesia, Cetakan Kedua. Jakarta: ICSD

Getol Gunadi. (2012). Management Miracles Series. Jakarta: PT Elex Media Komputindo

Ghozali, Imam dan Anis Chariri. (2007). Teori Akuntansi. Semarang: Badan Penerbit Universitas Diponegoro.

http://www.pikiranrakyat.com/nasional/2017/08/11/korupsidana-desa-kebanyakan-didalangi-kepaladesa-407195

https://antikorupsi.org/sites/default/files/outlook _desa_2018_-_icw.pdf

https://www.kemenkeu.go.id/

Hutapea dan Thoha. (2008). Kompetensi Plus Teori, Desain, Kasus dan Penerapan untuk $H R$ serta Organisasi yang dinamis. Jakarta: Gramedia

Indrawati. (2017). Pengaruh Kompetensi dan Komitmen Terhadap Kinerja Pengelola Keuangan. Palu: E-Jurnal Katalogis, Volume 5, No.5: hlm 189-197 
Jensen dan Meckling. (1976). Theory of the Firm: Managerial Behavior, Agency Costs and Ownership Structure. Hardvard University

Law No. 6 of 2014 concerning Village

Luthans, Fred. 2006. Perilaku Organisasi Edisi 10. Yogyakarta: PT. Andi.

Mada Sarifudin, Lintje Kalangi dan Hendrik Gamaliel. (2017). Pengaruh Kompetensi Aparat Pengelola Dana Desa, Komitmen Organisasi Pemerintah Desa, dan Partisipasi Masyarakat Terhadap Akuntabilitas Pengelola Dana Desa Di Kabupaten Gorontalo. E-Jurnal Magister Akuntansi Fakultas Ekonomi dan Bisnis Universitas Sam Ratulangi.

Mamahit, S. (2017). Peranan Badan Permusyawaratan Desa Dalam Pelaksanaan Fungsi Pengawasan Pada Pengelolaan Alokasi Dana Desa. E-Jurnal Universitas Sam Ratulangi.

Minister of Domestic Affairs Regulation No. 113 of 2014 concerning Village Financial Management.

Mondale, Fitrawan. 2017. Analisis Problematika Pengelolaan Keuangan Desa. Aceh : Jurnal Perspektif Ekonomi Darussalam, Volume 3, No.2: 25026976

Muis, Abdul, et al. (2015). Policy Paper Pengelolaan Keuangan Desa Pasca UU No. 6 Tahun 2014. Jakarta: Pusat Intan Lan.

Robbins, Stephen P., Judge, Timothy. 2002. Perilaku Organisasi Buku 2. Jakarta: Salemba Empat.

Sekaran, U. (2009). Research Methods for Business. Jakarta: Salemba Empat.
Sekaran U.,\& Bougie, R. (2013) Research Methhods for Business. Jakarta: Salemba Empat.

Setiana Novindra Dwi, dan Nur Laila Yuliani. (2017). Pengaruh Pemahaman dan Peran Perangkat Desa Terhadap Akuntabilitas Pengelolaan Keuangan Desa. Jurnal The $6^{\text {th }}$ University Colloquium 2017 Universitas Muhammadiyah Magelang.

Sevirna Ratri, A. S. (2017). Study for Community Empowerment and Rural Development. Surabaya.

S.Mulyani, E.Puspitasari dan DH. Yunita (2018). Analysis of the Critical Factors in Supporting the Implementation of the Accrual-based Accounting in the Local Government. Review of Integrative Business and Economic Research, Volume 7 , Supplementary Issue 1.

Sugiyono. (2015). Statistika Untuk Penelitian. Bandung: ALFABETA.

Sugiyono. (2017). Metode Penelitian Kuantitatif, Kualitatif dan $R \& D$. Bandung: Alfabeta.

Susanti. (2014). Pengawasan Badan Permusyawaratan Desa (BPD) Dalam Pengelolaan Alokasi Dana Desa (ADD) di Desa Kayungo Kecamatan Long Ikis Kabupaten Paser. E-Jurnal Ilmu Pemerintahan Universitas Mulawarman.

Yuliarta. (2013). Pengaruh Kompetensi Penatausahaan Keaungan, Sistem Pengendalian Intern Pemerintah dan Pengawasan Keuangan Daerah Terhadap Nilai Informasi Laporan Keuangan Pemerintah Daerah Kota Padang. Skripsi Fakultas Ekonomi Universitas Negeri Padang. 